
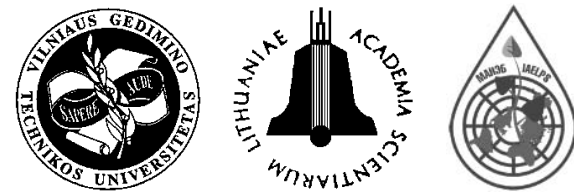

18(4): $321-328$

\title{
ANALYSIS OF NUMERICAL MODELLING OF TURBULENCE IN A CONICAL REVERSE-FLOW CYCLONE
}

\author{
Petras Vaitiekūnas ${ }^{1}$, Inga Jakštoniené ${ }^{2}$ \\ ${ }^{1,2}$ Dept of Environmental Protection, Vilnius Gediminas Technical University, \\ Saulètekio al. 11, LT-10223 Vilnius, Lithuania \\ E-mails: ${ }^{1}$ vaitiek@.vgtu.lt; ${ }^{2}$ ingajakstoniene@gmail.com
}

Submitted 10 Mar. 2010; accepted 14 Jun. 2010

\begin{abstract}
This paper aims to analyse the problem of numerical modelling of the airflow in a conical reverse-flow (CRF) cyclone with tangential inlet (equipment for separation of solid particles from gaseous fluid flow). A review of experimental and theoretical papers that describe cyclones with very complex swirling flow is performed. Three-dimensional transport differential equations for incompressible turbulent flow inside a cyclone are solved numerically using finite volume-based turbulence models, namely, the Standard $k-\varepsilon$ model, the RNG $k-\varepsilon$ model and the Reynolds stress model (RSM). The paper describes the numerical modelling of the airflow in the CRF cyclone, the height of which is $0.75 \mathrm{~m}$, diameter $-0.17 \mathrm{~m}$, height of cylindrical part $-0.255 \mathrm{~m}$, height of conical part $-0.425 \mathrm{~m}$, inlet area is $0.085 \times 0.032 \mathrm{~m}^{2}$. Mathematical model of airflow in a cyclone consisted of Navier-Stokes (Reynolds) three-dimensional differential equation system. Modelling results, obtained from the numerical tests when inlet velocity is 4.64, 9.0 and $14.8 \mathrm{~m} / \mathrm{s}$ and flow rate is, respectively, $0.0112,0.0245$ and $0.0408(0.0388) \mathrm{m}^{3} / \mathrm{s}$, have demonstrated a reasonable agreement with other authors' experimental and theoretical results. The average relative error was $\pm 7.5 \%$.
\end{abstract}

Keywords: cyclone, solid particles, numerical modelling, turbulence, one-phase, two-phase airflow.

\section{Introduction}

Theoretical and experimental studies of cyclones started in the $19^{\text {th }}$ century (Коузов 1993; Федоров и др. 2002; Ватин и Стрелец 2003).

In 1982, German Matthias Bohnet introduced the history of cyclones in his article "Cyclone separators for separation of gas/solids flow systems".

In 1886, O. M. Meursault obtained a patent for cyclone equipment even though it had been invented more than 100 years ago. Many scientists had performed experimental studies of cyclones. However, most probably very few people know that L. Prandlis provided and justified theoretical conclusions about mechanics of flows (Ватин и Стрелец 2003).

Cyclones are widely used in oil and recycling industries to separate particles from fluids. This happens because cyclones are easy to use, and they do not require heavy construction, exploitation, maintenance and energy consumption expenses. The use of appropriate materials and construction methods enables scientists to exploit cyclones at a high temperature and high pressure when the use of very efficient equipment can influence the following processes in energy and recycling industries pressurized fluidised-bed combustion (PFBC), integrated gasification combined cycle (IGCC) and fluidised catalytic cracking (FCC). In these processes, cyclones are now almost the only fully-commercial method to separate particles from high-temperature gases (Zhou and Sao 1990; Hu et al. 2005; Gujun et al. 2008).
Their constructions usually have tangential inlets and cyclones are defined as a funnel-shaped industrial inertial equipment. They are very popular because of being very simple; they are compact and cheap to produce; they have no moving parts and do not require much maintenance (Boysan et al. 1982; Bernardo et al. 2006; Jakštonienè, Vaitiekūnas 2009). Tangential inlet allows separating particles from gases (Altmeyer et al. 2004; Kaya and Karagoz 2008).

Computational fluid dynamics (CFD) has a great potential to predict the flow-field characteristics, particle trajectories (Baltrenas et al. 2008) and the pressure drop in cyclones (Gimbun et al. 2005).

Insufficient understanding of the process of twophase flow in a cyclone does not allow improving its exploitation. Such an inadequate understanding arises due to the fact that despite the supposed simplicity, dynamics of flows in cyclones is very complex and includes features such as swirling movement and in certain cases several reverse-flow circular zones. Theories of closed swirling flow have not yet succeeded in distinguishing many characteristics of the analysed flow. The problem of mathematical modelling of a detailed flow structure includes the solution of closely-related nonlinear partial differential equations of mass and impulse conservation and has no analytical solution. Besides, discontinuation of turbulence based on the assumption of isotropy (e.g. the $k-\varepsilon$ model) cannot be used for strongly swirling flows (Boysan et al. 1982; Bernardo et al. 2006). 
Hoffmann and Stein (2002) claim that the standard $k-\varepsilon \dot{\varepsilon}$ model has its own disadvantages when it is used for strongly swirling flows.

Meier and Mori (1999) provided timely-averaged Navier-Stokes equations for the gaseous phase and related them to the anisotropic turbulence model in combination with the $k-\dot{\varepsilon}$ model and algebraic stress equations. After this innovative work, several studies aimed to model turbulence in order to better foresee velocity and pressure when modifying turbulence models. All these studies accepted axial symmetry that allows using twodimensional model where the solid phase almost does not contact the gaseous field.

Bernardo et al. (2006) used a specific turbulence model, known as the Reynolds stress model (RSM), to find certain values for Reynolds stress terms. This model is based on transport equations for all the Reynolds stress tensor components and dissipation velocity. RSM provides anisotropic turbulence to flows; when the hypothesis of turbulent viscosity is used, the model gives isotropic turbulence. In the first case, Reynolds stress transfer equations are solved for separate stress components.

Wang et al. (2006) applied RSM in order to model gas flow in the Lapple cyclone. RSM very precisely predicts swirling flow features, axial velocity, tangential velocity and pressure loss in the model of a cyclone (Sommerfeld 2003; Gujun et al. 2008). The following mathematical model can be drawn in this case:

$$
\frac{D u}{D t}=\rho F_{i}-\frac{\partial p}{\partial x_{i}}+\frac{\partial}{\partial x_{j}}\left(\mu \frac{\partial u_{i}}{\partial x_{j}}-\overline{\rho u_{i}^{\prime} u_{j}^{\prime}}\right),
$$

$i, j=1,2,3$. Terms in the (1)-type equations $\overline{\rho u_{i}^{\prime} u_{j}^{\prime}}$ are called turbulent or Reynolds stresses that require additional differential equations. For this purpose, Reynolds stress equations are used. These equations for the twodimensional problem are described in the Kavaliauskas and Vaitiekūnas (2001) study. RSM (Reynolds stress model) can reasonably predict swirling flows (Gujun et al. 2008). The probabilistic Lagrange model is used in order to model the flow of particles.

The aim of this work is to analyse numerical methods that describe the motion of flow in cyclones and to perform numerical modelling of airflow in a cyclone. For this purpose, three-dimensional transport equations with the standard $\mathrm{k}-\varepsilon$, RNG $\mathrm{k}-\varepsilon$ and RSM turbulence model are used.

\section{Governing equations and solution method}

Turbulent flows are very complex. This is clearly seen in the increased complexity of turbulent velocity equations (such as 1) where additional terms (Reynolds stresses) are used. When modelling these terms, we try to provide simple connections as the finite equation form that is solved numerically (simplification of the full equations). This means that the accuracy of the mathematical model that describes flow can be reduced (Vaitiekūnas 1998).
The use of the hypothesis of turbulent viscosity allows forming the following differential transport equations:

$$
\operatorname{div}\left(\rho \overrightarrow{\mathbf{V}} \Phi-\Gamma_{\Phi} \operatorname{grad} \Phi\right)=S_{\Phi},
$$

where $t$-time; $\rho$-density; $\Phi$-dependent variable, as a moment to the unit of mass, turbulence energy, its dissipation velocity; when $\Phi=1-$ continuity equation $\overrightarrow{\mathbf{v}}$; velocity vector; $\Gamma$ - exchange coefficient of the variable $\Phi ; S_{\Phi}-$ flow (source) term to variable $\Phi$. Exchange coefficient for the turbulent flow can be written as:

$$
\Gamma_{\phi}=\rho\left(v_{l}+v_{t}\right)
$$

where $v_{l}$ - molecular coefficient of kinematic viscosity, $v_{t}$ - coefficient of turbulent viscosity. The turbulent viscosity $\mu_{T}$ or $\nu_{T}$ can be computed by combining the turbulent kinetic energy $k$ and its dissipation rate $\varepsilon$ as follows:

$$
\mu_{T}=C_{\mu} \rho \frac{k^{2}}{\varepsilon} \text {. }
$$

Transport equations for variables $k$ and $\varepsilon$ in the RNG $k-\varepsilon$ model, which is derived from Navier-Stokes equations using the renormalisation group theory (Yakhot and Orszag 1986) can be written as:

$$
\begin{gathered}
\rho \frac{D k}{D t}=\frac{\partial}{\partial x_{i}}\left(a_{k} \mu_{e f f} \frac{\partial k}{\partial x_{i}}\right)+G_{k}-\rho \varepsilon \\
\rho \frac{D \varepsilon}{D t}=\frac{\partial}{\partial x_{i}}\left(a_{k} \mu_{e f f} \frac{\partial k}{\partial x_{i}}\right)+C_{1 \varepsilon} \frac{\varepsilon}{k} G_{k}-C_{2 \varepsilon} \rho \frac{\varepsilon^{2}}{k}-R .
\end{gathered}
$$

Unlike the standard $k-\varepsilon$ model, this model includes analytical expressions in addition to having an extra term $R$ in the second equation. The model constants are assumed to have the following values: $C_{1 \varepsilon}=1.42, C_{2 \varepsilon}=1.68$ and $C_{\mu}=0.0845, \operatorname{Pr}_{k, T}=\operatorname{Pr}_{\varepsilon, T}=0.7194$.

These governing equations are solved numerically using the finite volume-based method (Spalding 2002; Patankar 1980). According to the basic idea of this finite volume-based method, the computational domain is divided into a number of cells, and differential equations are integrated over each cell using the theorem of divergence (the Gaus-Ostrogradski theorem) to obtain algebraic equations. These algebraic equations are solved iteratively to obtain the field distribution of dependent variables.

\section{Modelling results and analysis}

A cyclone consists of three main parts: an inlet, a separation chamber and dust chamber. The Stairmand highefficiency cyclone (Kaya and Karagoz 2008) was used in this study (Fig. 1a) provides geometric configuration of a cyclone: general cyclone height $-0.75 \mathrm{~m}$, height of cylindrical part $-0.255 \mathrm{~m}$, height of conical part $-0.425 \mathrm{~m}$, diameter $-2 R=0.17 \mathrm{~m}$.

Governing equations were solved numerically using the finite volume-based CFD method. The use of CFD when modelling flow in cyclones is the best decision as this method is more universal. The use of the optimum modelling scheme CFD allows recording complex flowparticle interaction with a great accuracy (Youngmin et al. 1999). 
Numerical modelling was performed with a numerical calculation grid where the cyclonic area is a threedimensional space in the cylindrical coordinate system that is divided into cells $x, y, z$.

In general, the cellular region of a cyclone is formed of $x \times y \times z=60 \times 15 \times 45=40500$ (Fig. 1b) volume cells and $x \times y \times z=60 \times 20 \times 45=54000$. These are control velocity cells where velocity components, pressure and turbulent characteristics in radial, tangential and axial directions are calculated.

Airflow velocity at the cyclone inlet is assumed to be uniformed and reaches $14.8 \mathrm{~m} / \mathrm{s}$; flow rate is $0.204 \mathrm{~m}^{3} / \mathrm{s}$ (other velocities: 4.64 and $9 \mathrm{~m} / \mathrm{s}$ ). The outflow boundary condition was used at the exit. At the walls, the law of flow-solid wall adhesion was applied for velocity, and near-wall treatment was achieved using the standard and non-equilibrium wall functions (Spalding 2002).

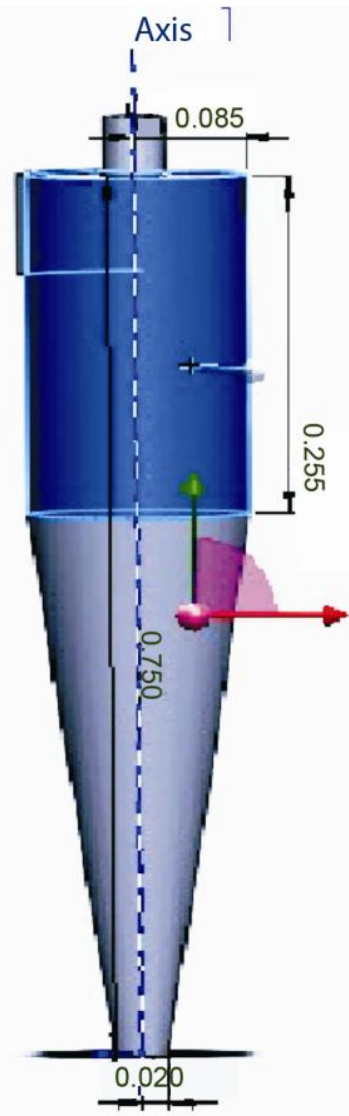

a)

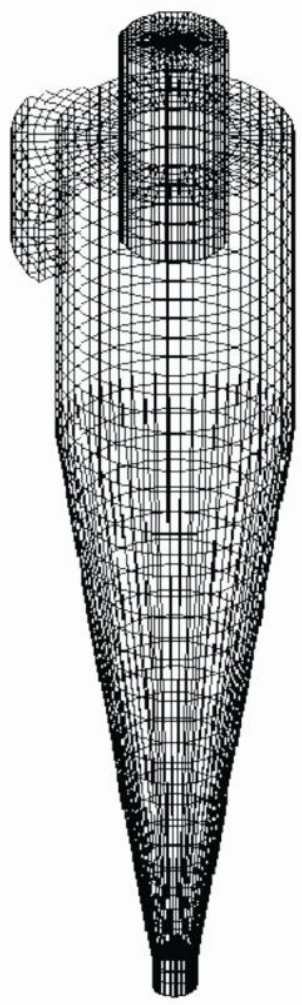

b)
Fig. 1. Cyclone geometry, inlet (at the top of cylindrical part, inflow cross-section area is $85 \times 32 \mathrm{~mm}$ ). Two outlets: downward - for solid particles, a tube at the top - for cleaned air (a); the outline of a calculation grid (b)

\subsection{Comparison of results}

Turbulent flow inside a tangential inlet cyclone was solved numerically using the CFD method with three different turbulence models, namely the standard $k-\varepsilon$, the RNG $k-\varepsilon$ turbulence model with non-equilibrium wall function and the RSM model. The received numerical results were compared with theoretical (Kaya and Karagoz 2008; Ber- nardo et al. 2006) as well as experimental (Patterson and Munz 1996; Cristea et al. 1996) data.

\subsection{Comparison of turbulence models}

The complicated swirling turbulent flow in a cyclone places great demands on the numerical methods and turbulence models employed in the CFD codes when modelling the cyclone pressure drop as well as axial and tangential velocities (Hoekstra et al. 1999; Ingham and Ma 2002).

Although literature widely analyses and describes turbulent transport models of various complexity used in numerical investigations, it is not yet clear which of them are the most appropriate for mixed convection.

Kaya and Karagoz (2008) analysed the performance of various numerical methods and interpolation schemes when studying strongly swirling flows inside a tangential inlet cyclone and compared predictable results with experimental data and numerical values of Gong and Wang (2004).

Comparison of axial and tangential velocity profiles computed using three turbulence models with experimental (Gong and Wang 2004) data is given in Figs. 2 and 3 , at different axial positions $\mathrm{z}$, below the top of the cylindrical cyclone. Zero value on the radial axis characterizes the centre of the cyclone. It was noted that the RSM turbulence model gives more coincident results than other turbulence models when comparing experimental data.

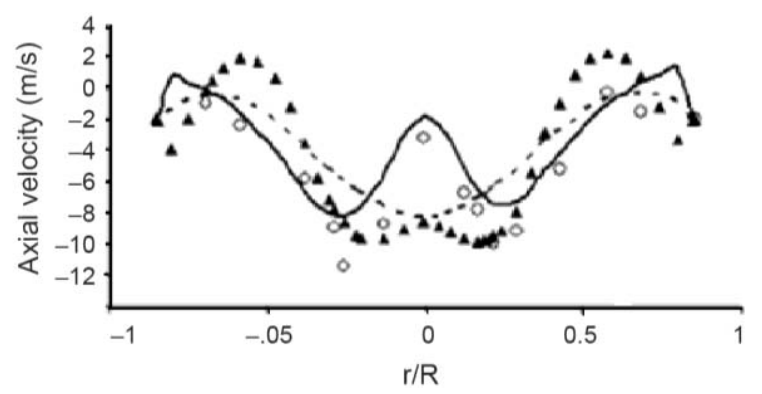

Fig. 2. Comparison between computed axial velocity profiles (RSM model: continuous curve; RNG: triangular spots; $\mathrm{k}-\mathrm{e}$ : dotted line) and experimental (white balls) data by Gong and Wang (2004) (axial position below the top of a cyclone $\left.\mathrm{z}=0.15 \mathrm{~m}, 90-270^{\circ}\right)$

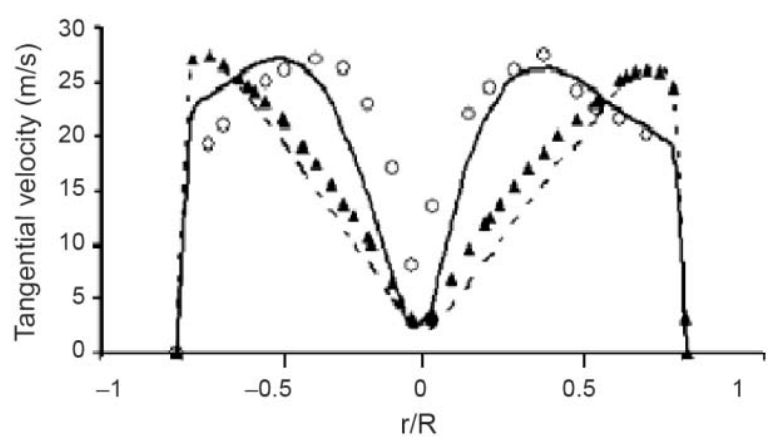

Fig. 3. Comparison between computed tangential velocity profiles (RSM model: continuous curve; RNG: triangular spots; $\mathrm{k}-\mathrm{e}$ : dotted line) and experimental (Gong and Wang 2004) data white balls (axial position below the top of a cyclone $\mathrm{z}=0.4 \mathrm{~m}$, $\left.0-180^{\circ}\right)$ 
Although the tendency and behaviour of theoretical velocity profiles are consistent with experimental data, there are some discrepancies, especially in the core part, when comparing the measured velocities from literature and the RSM predictions. When this swirling flow is strongly affected by the flow and geometric conditions, and it is difficult to measure velocities precisely in such a complex flow, a conclusion can be drawn that these discrepancies are due to not only turbulence models and numerical methods, but also due to experimental and measurement errors. The highly rotating fluid flow generates strong anisotropy in the turbulent structure. This causes the standard $k-\varepsilon$ and the RNG $k-\varepsilon$ turbulence models to provide inaccurate predictions for the fluid flow. Although the RNG $k-\varepsilon$ model gives slightly better results when compared to the standard $k-\varepsilon$ model, it fails to provide Rankin-type velocity distributions due to its swirl (see Fig. 3). Besides, the standard $k-\varepsilon$ and the RNG $k-\varepsilon$ turbulence models over predict the pressure drop. However, the best prediction of the pressure drop is given by the RSM model. This is also confirmed by the modelling results of the work (Kaya and Karagoz 2008).

\subsection{Velocity fields in a cyclone}

Comparison of velocity vectors with the inlet velocities of 4.64 and $14.8 \mathrm{~m} / \mathrm{s}$ is given in Figs. $4 \mathrm{a}$ and $4 \mathrm{~b}$.

Fig. $4 \mathrm{~b}$ presents a different velocity field, especially in the conical part of a cyclone. Different inlet velocities present a complex flow field, where flow velocity increases towards the cone apex due to acceleration and spiral-shaped inner vortex. Fig. 5 illustrates velocity contours, respectively, tangential U1 and axial W1.

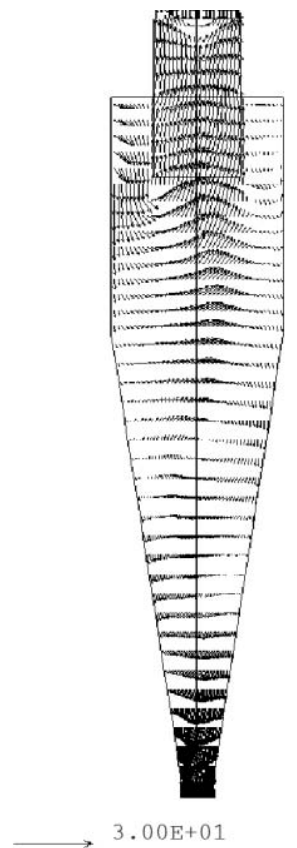

a)

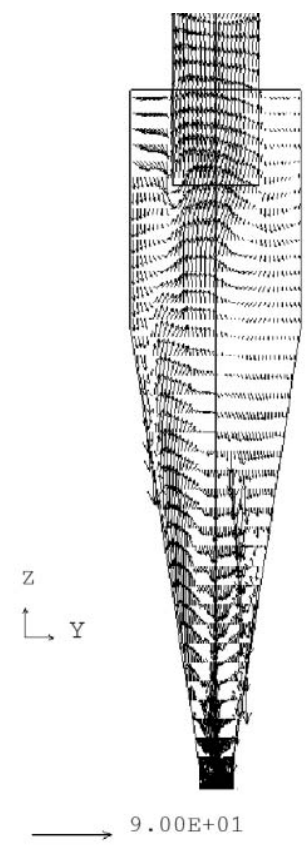

b)
Fig. 4. Field of velocity vectors in the vertical plane of a cyclone cross-section with the inlet velocity of $4.64 \mathrm{~m} / \mathrm{s}$. Scale of vectors (Fig. below) is $30.0 \mathrm{~m} / \mathrm{s}$ (a); field of velocity vectors in the vertical plane of a cyclone cross-section with the inlet velocity $14.8 \mathrm{~m} / \mathrm{s}$. Scale of vectors (below) is $90.0 \mathrm{~m} / \mathrm{s}$ (b)

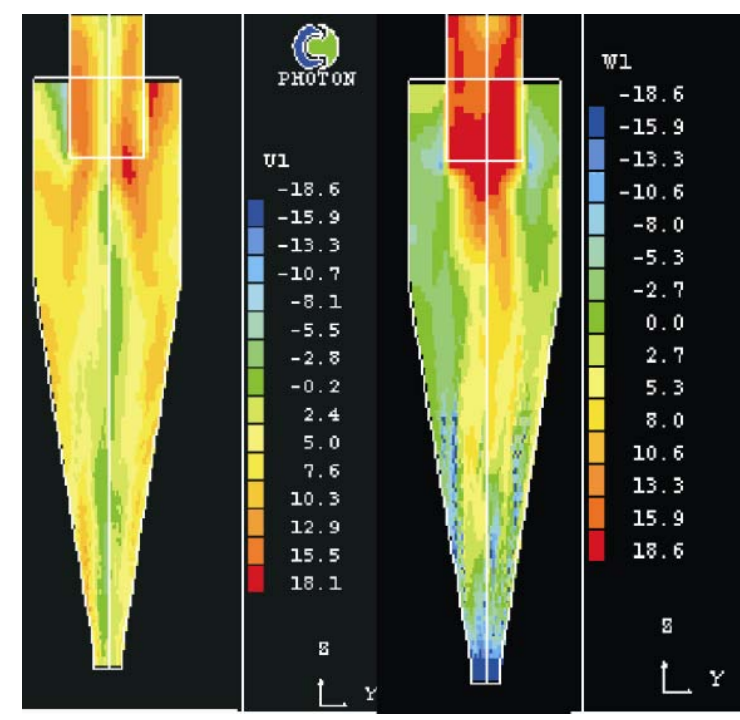

a)

b)

Fig. 5. RNG turbulence model with the tangential inlet velocity of $14.8 \mathrm{~m} / \mathrm{s}$ : a) contours of tangential velocity U1 component in the vertical plane of a cyclone; b) contours of axial velocity $\mathrm{W} 1$ component in the vertical plane of a cyclone

Figs. 5a and 5b present colour contours of the velocity component projection at the $\mathrm{z}$ coordinate in the vertical plane $\mathrm{W} 1$ and $\mathrm{U} 1$. These contours indicate movement directions for the flow velocity components inside a cyclone.

Pressure measurements. Presence of high-pressure gradients and double-vortex flow structure requires an efficient algorithm for pressure computations. Fig. 6 presents contours of pressure P1 in the vertical plane of a cyclone. High-pressure gradients and double-vortex flow structure require an efficient algorithm for the pressure measurements.

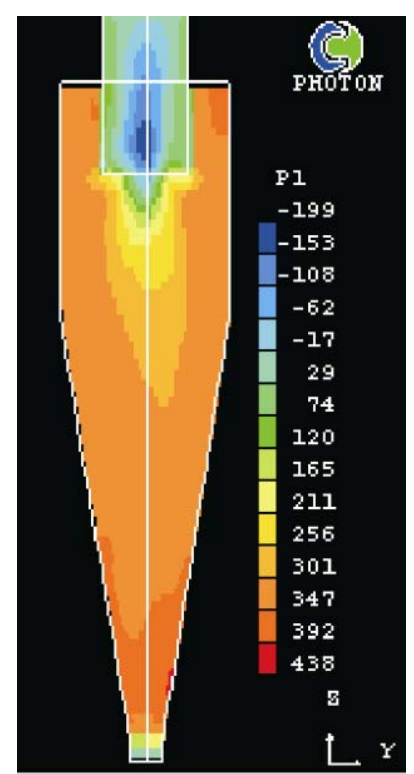

Fig. 6. RNG turbulence model. Contours of pressure P1 in the vertical plane of a cyclone with the tangential inlet velocity of $14.8 \mathrm{~m} / \mathrm{s}$ 
Numerical analysis of this problem was performed in a specific study (Kaya and Karagoz 2008). It has been determined that the presto pressure interpolation scheme is successful in this respect. It enables to reproduce the pressure field and a very accurate velocity field. Among the numerical solutions with the presto scheme, the best results for pressure drop are obtained with numerical solution, where the Simplec algorithm is used for pressure-velocity coupling and the Quick scheme is used for the momentum equation. The Quick scheme can be used to calculate momentum, turbulent kinetic energy and its dissipation rate equations. The Quick scheme helps to minimize any artificial viscosity that may be introduced into the discretized form of the governing equations.

Comparison of numerical axial velocity profiles performed by the RSM model and experimental (Gong and Wang 2004) data is given in Fig. 7, at the axial position of $\mathrm{z}=0.15 \mathrm{~m}$, below the top of the cylindrical cyclone body. Positive velocities (up to $2 \mathrm{~m} / \mathrm{s}$ ) are directed towards the top outlet. There is the other region close to the wall of the cyclone where the flow is directed downwards (Fig. 4). The axial velocity displays a two-peak distribution in the interior flow at the upper region of a cyclone. The axial velocity gradually decreases towards the centre to a minimum, which may even be negative in some axial positions (Fig. 4). At about two-thirds of the cyclone radius, the flow reverses. Although the numerical solution over predict the maximum velocities in the core region, it well confirms the fact that the used numerical techniques give reasonable results in agreement with the experimental data. Differences between the numerical calculations are close to each other.

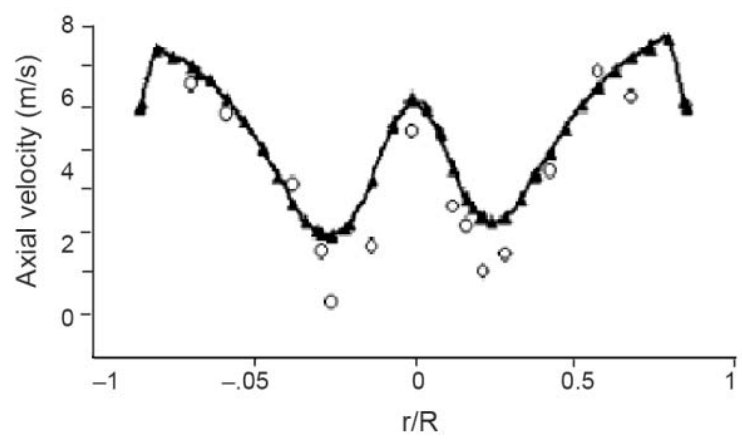

Fig. 7. Comparison between the computed axial velocity profiles (a curve through triangular spots) and experimental (balls) (Gong and Wang 2004) data (axial position at $0.15 \mathrm{~m}$ below the top of a cyclone)

Comparison between the received and previous (Kaya and Karagoz 2008) numerical axial and tangential velocity contours has shown that in the vertical plane, the form of axial velocity profiles changes significantly and differences among numerical solutions are noticeable. This happens because the flow rotates downwards towards the top of the conical part. At $\mathrm{z}=0.65 \mathrm{~m}$, different velocity values are received.

Bernardo et al. (2006) gave a comparison between the numerical and experimental tangential velocities of gases at two axial positions, respectively, $0.12 \mathrm{~m}$ and

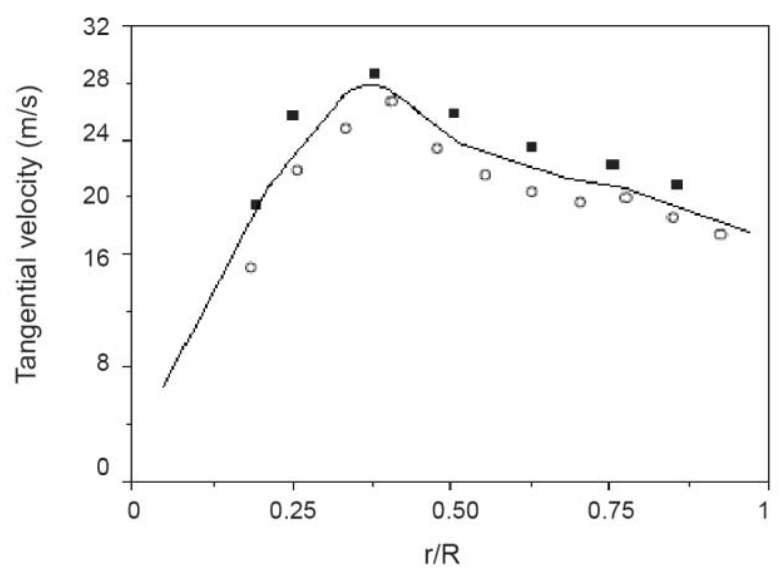

Fig. 8. Comparison between tangential velocity profiles and experimental data (axial position is $0.12 \mathrm{~m}$ from the top of a cyclone, inlet velocity $-15.2 \mathrm{~m} / \mathrm{s}$ ): curve - results of the modelling of this study, black dots - experimental (Patterson and Munz 1996) data, white balls - numerical (Bernardo et al. 2006) results

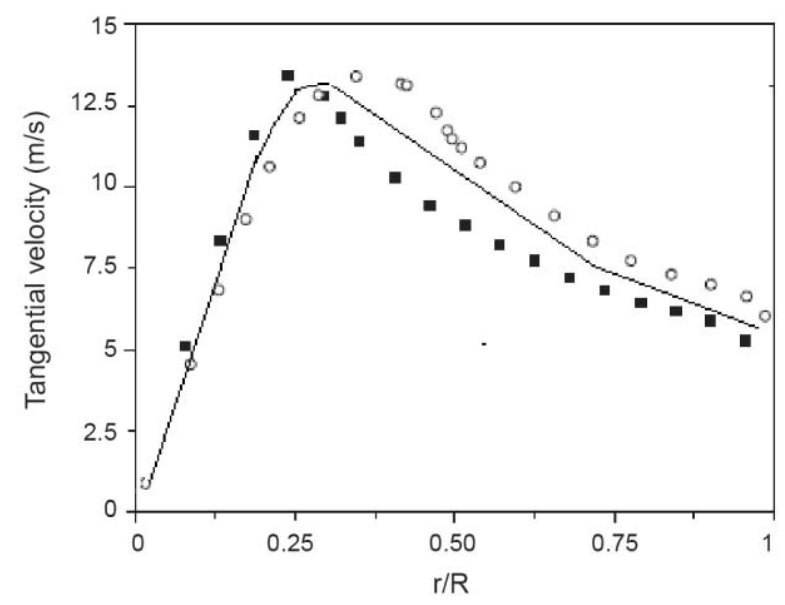

Fig. 9. Comparison between tangential velocity profiles and experimental data (axial position is $0.33 \mathrm{~m}$ from the top of a cyclone, inlet velocity $4.64 \mathrm{~m} / \mathrm{s}$ ): curve - results of the modelling of this study, black dots - experimental (Cristea et al. 1996) data, white balls - numerical (Bernardo et al. 2006) results

$0.33 \mathrm{~m}$ from the top of a cyclone. These results were received with the one-phase turbulence model (Figs 8,9).

Among the numerical solutions with the presto scheme, the best results for pressure drop are obtained with a numerical solution when the Simplec algorithm is used for pressure-velocity coupling and the Quick scheme is used for momentum equation. The Quick scheme can be used to calculate momentum, turbulent kinetic energy and its dissipation rate equations. The Quick scheme can reduce any artificial viscosity that can be introduced into the discretized form of the governing equations (Kaya and Karagoz 2008).

Comparison of the two isotropic turbulent models, namely, $k-\varepsilon$ and $\mathrm{RNG} k-\varepsilon$ turbulent model, and the Reynolds stress model (RSM), which is an anisotropic turbulent model, with the theoretical Kaya and Karagoz (2008) data has shown a good equivalence according to certain turbulence models. Numerical results have shown 
that the success of CFD is influenced by the accurate description of the turbulent movement of the flow and the use of the most appropriate numerical methods and interpolation schemes.

Figs. 2 and 3 give a comparison at different axial positions $\mathrm{z}$, below the top of a cyclone. Zero value on the radial axis characterizes the centre of a cyclone. Kaya and Karagoz (2008), Bernardo et al. (2006) have found that the results confirm that the RSM turbulence model gives better results than other turbulence models. Although the tendency and behaviour of the theoretical velocity profiles are consistent with experimental data, there are some discrepancies, especially in the core part, when comparing the measured velocities from literature and the RSM predictions. When this swirling flow is strongly affected by the flow and geometric conditions, and it is difficult to measure velocities precisely in such a complex flow, the authors draw a conclusion that these discrepancies are due to not only turbulence models and numerical methods, but also due to experimental and measurement errors. The highly-rotating fluid flow generates strong anisotropy in the turbulent structure. This causes the standard $k-\varepsilon$ and the RNG $k-\varepsilon$ turbulence models to provide inaccurate predictions for the fluid flow. Kaya and Karagoz (2008) claim that RNG $k-\varepsilon$ model gives slightly better results when compared to the standard $k-\varepsilon$ model; however, it fails to provide Rankin-type velocity distributions due to its swirl (see Fig. 3). Besides, the standard $k-$ $\varepsilon$ and the RNG $k-\varepsilon$ turbulence models do not predict the pressure drop. However, the best prediction of the pressure drop is given by the RSM model.

Fig. 3 gives a comparison between numerical and experimental results of tangential velocities at the axial position of $\mathrm{z}=0.4 \mathrm{~m}$ from the top of a cyclone. The fluid flow in a cyclone indicates the Rankin-type vortex, which is a combination of free and forced vortices, and well predicted by numerical simulations with the RSM model. Besides, the axis of the vortex does not coincide with the geometrical axis of a cyclone due to the asymmetric location of the inlet. In the central region of a cyclone, where the flow rotates like a solid body because of forced vortex, tangential velocity increases with the increasing radius. The maximum computed tangential velocity of approximately 1.82 times of the inlet velocity is reached at about half of the radius. As can be seen in Fig. 3, the maximum of the tangential velocity is increased in the modeling results.

With the tangential inlet velocity of $9.8 \mathrm{~m} / \mathrm{s}$, profiles in the radial plane of tangential velocity cyclone at $\mathrm{z}=0.19 \mathrm{~m}$ from the top of a cyclone show similar results to the experimental (Cristea et al. 1996) data. The maximum tangential velocity at $\mathrm{r} / \mathrm{R}=0.25$ is about $8 \mathrm{~m} / \mathrm{s}$; for modelling - about $7 \mathrm{~m} / \mathrm{s}$ and the maximum is at $\mathrm{r} / \mathrm{R}=$ 0.35 and reaches $7.5 \mathrm{~m} / \mathrm{s}$. Thus, with low inlet velocities (4.64 and $9.8 \mathrm{~m} / \mathrm{s}$ ), aerodynamic processes are not as complex as they are with the velocity of $15 \mathrm{~m} / \mathrm{s}$. Besides, modelling results give reasonable results in agreement with the experimental data.

\section{Conclusions}

1. This paper provides a theoretical analysis of turbulence models in the swirling flow of a conical reverseflow cyclone with tangential inlet. Three turbulent models $(k-\varepsilon$, RNG $k-\varepsilon$ and RSM) are used and numerical results are provided. The RSM model is the most appropriate for the measurement of aerodynamic processes in cyclones with axial flow rotation.

2. The standard $k-\varepsilon$ and RNG $k-\varepsilon$ models are better at modelling rotation of solid bodies than at receiving combined vortices. These models also provide unrealistic distribution of axial velocity. They should not be used at modelling strongly swirling flows.

3. Comparison of the finite elements and finite volume methods has shown that the results indicate agreement in modelling analogical cyclone flows.

4. Comparison of modelling results (profiles of axial and tangential velocities) and experimental data have shown a reasonable agreement. The average relative error was approximately $7.5 \%$.

The scientific research is supported by the COST activity No MP0806 "Particles in turbulence" which is supported by International Science and Technology Development Programme Agency.

\section{References}

Altmeyer, S.; Mathieu, V.; Jullemier, S.; Contal, P.; Midoux, N.; Rode, S.; Leclers, J. P. 2004. Comparison of different models of cyclone prediction performanse for various operating cinditions usting a general software, Chem. Eng. Prog. 43: 511-522. doi:10.1016/S0255-2701(03)00079-5

Baltrènas, P.; Morkūnienè, J.; Vaitiekūnas, P. 2008. Numerical simulation of solid particle dispersion in the air of Vilnius City, Journal of Environmental Engineering and Landscape Management 16(1): 15-22. doi:10.3846/1648-6897.2008.16.15-22

Bernardo, S.; Mori, M.; Peres, A. P.; Dionı'sio, R. P. 2006. 3-D computational fluid dynamics for gas and gas-particle flows in a cyclone with different inlet section angles, Powder Technology 162(2006): 190-200. doi:10.1016/j.powtec.2005.11.007

Boysan, F.; Ayers, W. H.; Swithenbank, J. A. 1982. A fundamental mathematical modeling approach to cyclone design, Institution of Chemical Engineers 60: 222- 230.

Cristea, E. D.; Malfa, E.; Coghe, A. 1996. 3-D numerical simulation and measurement of strongly swirling heavy dustladen flow inside a cyclone separator, in $3^{\text {rd }}$ International Symposium on Engineering Turbulence Modeling and Measurements. Crete, Greece.

Derksen, J. J. 2003. Separation performance predictions of a Stairmand high efficiency cyclone, AIChE Journal 49: 1359-1371. doi:10.1002/aic.690490603

Fluent, Inc. 2004. Fluent 6.1.22 Users` Guide.

Gimbun, J.; Chuah, T. G.; Fakhru'l-Razi, A.; Choong, T. S. Y. 2005. The influence of temperature and inlet velocity on cyclone pressure drop: A CFD study, Chem. Eng. Prog. 44: 7-12. doi:10.1016/j.cep.2004.03.005

Gong, A. L.; Wang, L. Z. 2004. Numerical study of gas phase flow in cyclones with the repds, Aero Technology 38: 506-512. doi:10.1080/02786820490449548 
Gujun, W.; Guogang, S.; Xiaohu, X.; Mingxian, S. 2008. Solids concentration simulation of different size particles in a cyclone separator, Powder Technology 183(2008): 94104. doi:10.1016/j.powtec.2007.11.019

Hoekstra, A. J.; Derksen, J. J.; Van Den Akker, H. E. A. 1999. An experimental and numerical study of turbulent swirling flow in gas cyclones, Chem. Eng. Sci. 54: 2055-2065. doi:10.1016/S0009-2509(98)00373-X

Hoffmann, A. C.; Stein, L. E. 2002. Gas Cyclone and Swirl Tubes-Principles, Design and Operation. SpringerVerlag, Berlin.

Hu, L. Y.; Zhou, L. X.; Zhang, J.; Shi, M. X. 2005. Studies on strongly swirling flows in the full space of volute cyclone separator, AIChE Journal 51(3): 740-749. doi:10.1002/aic.10354

Ingham, D. B.; Ma, L. 2002. Predicting the performance of air cyclones, Int. J. Energy Res. 26: 633-652. doi:10.1002/er.808

Jakštoniene, I; Vaitiekūnas, P. 2009. Applaying computational fluid dynamics modelling for investigating conical reverse-flow cyclone, Mokslas - Lietuvos ateitis. Aplinkos apsaugos inžinerija 1(4): 51-55. Vilnius. ISBN 9789955-28-162-7.

Kavaliauskas, A.; Vaitiekūnas, P. 2001. Modelling of Reynolds stresses in overflowing air stream in a square channel, Energetika (3): 38-43.

Kaya, F.; Karagoz, I. 2008. Performance analysis of numerical schemes in highly swirling turbulent flows in cyclones, Current Science 94(10):1273-1278.

Liden, G.; Gudmundsson, A. 1997. Semi-empirical modelling to generalise the dependence of cyclone collection efficiency on operating conditions and cyclone design, $J$. Aerosol Sci. 28(5): 853. doi:10.1016/S0021-8502(96)00479-X

Ma, H.; Ingham, D. B.; Wen, X. 2000. Numerical modelling of the fluid and particle penetration through small sampling cyclones, Elsevier Science, Great Britain 31(9): 1097-1119.

Meier, M.; Mori, M. 1999. Anisotropic behavior of the Reynolds stress in gas and gas - solid flows in cyclones, Powder Technology 101(1999): 108-119. doi:10.1016/S0032-5910(98)00162-4

Morsi, S. A.; Alexander, A. J. 1972. An investigation of particle trajectories in twophase flow systems, Journal of Fluid Mechanics 55 (2):193-208. doi:10.1017/S0022112072001806

Patankar, S. V. 1980. Numerical Heat Transfer and Fluid Flow. Hemisphere (McGraw-Hill), New York, 176.
Patterson, P. A.; Munz, R. J. 1996. Gas and particle flow patterns in cyclones at room elevated temperatures, Canadian Journal of Chemical Engineering 74: 213-221. doi:10.1002/cjce.5450740206

Petraitis, E.; Vasarevičius, S. 2001. Numerical modelling of solid particle dispersion in the atmosphere using the programs "VARSA" and "PHOENICS", Journal of Environmental Engineering and Landscape Management 9(1): 23-28.

Sommerfeld, M.; Ho, C. H. 2003. Numerical calculation of particle transport in turbulent wall bounded flows, Powder Technology 131: 1-6. doi:10.1016/S0032-5910(02)00293-0

Spalding, D. B. 2002. PHOENICS 3.5 VR CFD codes. Available from Internet: <http://cham.co.uk/>.

Vaitiekūnas, P. 1998. Numerical modelling of convective transfer. Kaunas: Lithuanian energy institute. $261 \mathrm{p}$.

Wang, B.; Xu, D. L.; Chu, K. W.; Yu, A. B. 2006. Numerical study of gas-solid flow in a cyclone separator, Applied Mathematical Modelling 30: 1326-1342. doi:10.1016/j.apm.2006.03.011

Yakhot, V.; Orszag, S. A. 1986. Renormalization group analysis of turbulence. I. Basic theory, J. Sci. Comput. 1: 1-51. doi:10.1007/BF01061452

Youngmin, J.; Chi, T.; Madhumita, B. Ray. 1999. Development of a post cyclone to improve the efficiency of reverse flow cyclones, Powder Technology 113(2000): 97-108. doi:10.1016/S0032-5910(00)00206-0

Zhao, B.; Su, Y.; Zhang, J. 2006. Simulation of gas flow pattern and separation efficiency in cyclone with conventional single and spiral double inlet configuration, Trans IChemE. PA, Chemical Engineering Research and Design 84: 1158-1165. doi:10.1205/cherd06040

Zhoue, L. X.; Soo, S. L. 1990 Gas solid flow and collection of solids in a cyclone separator, Powder Technology 63(1): 45-53. doi:10.1016/0032-5910(90)80006-K

Ватин, Н. И.; Стрелец, К. И. 2003. Очистка воздуха при помощии аппаратов типа циклон. Санкт-Петербург. $14 \mathrm{c}$.

Коузов, П. А.; Мальгин, А. Д.; Скрябин, Г. М. 1993. Очистка газов и воздуха от пыли в химической промышленности. СПб: Химия. $320 \mathrm{c.}$

Федоров, Б. С.; Чекалов, Л. В. и др. 2002. Экотехника. Экологический консорииум „РОСГАЗООЧИСТКА“. Режим доступа: <http://kondore.newmail.ru/Kniga_20.05. 2002>.

\section{DUJŲ AERODINAMIKOS KŪGINIAME TURBULENTINIO GRĮŽTAMOJO SRAUTO CIKLONE SKAITINIO MODELIAVIMO ANALIZE்}

\section{P. Vaitiekūnas, I. Jakštonienė}

Santrauka

Nagrinejjama dujų aerodinamikos kūginiame grį̌tamojo srauto (KGS) ciklone (įrenginys kietosioms dalelèms atskirti iš oro srauto) su tangentiniu srauto ịtekẻjimu skaitinio modeliavimo problema. Trimatès nespūdžiojo turbulentinio srauto ciklono viduje pernašos diferencialinès lygtys skaitiškai spręstos baigtinių tūrių metodu taikant standartinị $k-\varepsilon$, RNG $k-\varepsilon$ ir Reinoldso ittempių (RIM) turbulencijos modelius. Atliktas skaitinis oro srauto judejjimo KGS ciklone modeliavimas. Ciklono aukštis $-0,75 \mathrm{~m}$, skersmuo $-0,17 \mathrm{~m}$, cilindrinès dalies aukštis $-0,255 \mathrm{~m}$, kūginès $-0,425 \mathrm{~m}$, įtekèjimo angos plotas $0,085 \times 0,032 \mathrm{~m}^{2}$. Oro srauto judejjimo ciklone matematinis modelis - Navjë ir Stokso (Reinoldso) trimačių diferencialinių lygčių sistema. Modeliavimo rezultatai, kai įtekèjimo greitis 4,64, 9,0 bei 14,8 m/s ir debitas - 0,0112, 0,0245 ir $0,0408(0,0388) \mathrm{m}^{3} / \mathrm{s}$, neblogai sutapo su kitų autorių eksperimentiniais rezultatais. Vidutinè santykinė paklaida \pm 8 proc.

Reikšminiai žodžiai: ciklonas, kietosios dalelès, skaitinis modeliavimas, turbulentumas, vienfazis, dvifazis oro srautas. 


\section{АНАЛИЗ ЧИСЛЕННОГО МОДЕЛИРОВАНИЯ ТУРБУЛЕНЦИИ ВОЗВРАТНОГО ПОТОКА В КОНИЧЕСКОМ ЦИКЛОНЕ}

\section{П. Вайтекунас, И. Якштонене}

\section{Рез юме}

Анализируется проблема аэродинамики газового потока в коническом возвратного потока (КВП) циклоне (оборудование для отделения твердых частиц от газового потока) с тангенциальной подачей газа. Произведен обзор экспериментальных и теоретических работ в циклонах такого типа, в которых образуется сложное вихревое течение потока. Для моделирования использованы трехмерные дифференциальные уравнения переноса, численно решаемые методом конечных объемов с использованием следующих моделей: стандартной $k-\varepsilon, \mathrm{RNG} k-\varepsilon$ и рейнольдсовой модели турбулентности напряжений. Произведено численное моделирование движения потока воздуха в циклоне КВП, высота которого 0,75 м, диаметр - 0,17 м, высота цилиндрической части - 0,255 м, конической части $-0,425$ м, площадь входного отверстия - 0,085×0,032 м². Математическую модель движения потока воздуха в циклоне составила система трехмерных дифференциальных уравнений Навье-Стокса и Рейнольдса. Анализ результатов, произведенный при скоростях втекания в циклон 4,64, 9,0 и 14,8 м/с (дебит - 0,0112, 0,0245 и $0,0408 \mathrm{~m}^{3} / \mathrm{c}$ ) и для модели рейнольдсовых напряжений, показал приемлемую согласованность с результатами других исследователей - со средней относительной погрешностью \pm 7,5 проц.

Ключевые слова: циклон, твердые частицы, численное моделирование, турбулентность, одна фаза, двухфазовый поток флюида.

Petras VAITIEKŪNAS. Dr Habil, Prof. Dept of Environmental Protection, Vilnius Gediminas Technical University (VGTU). Doctor Habil of Science (energy and thermal engineering), Lithuanian Energy Institute, 1999. Doctor of Science Laboratory of Fluid Dynamics in Heat Exchangers, Lithuanian Energy Institute, 1972. Employment: Professor (2002), Associate Professor (1997). Publications: author of 1 monograph, 3educational books, over 230 research papers. Membership: prize-winner of the Republic of Lithuania (2006), a corresponding member of International Academy of Ecological and Life Protection Sciences. Research interests: hydrodynamics, convective heat and mass transfer and thermophysics, conputational fluid dynamics, mathematical modeling of transfer processes in the environment.

Inga JAKŠTONIENĖ. Master, PhD student (2009), Dept of Environmental Protection, Vilnius Gediminas Technical University (VGTU).

Master of Chemical Engineering, Kaunas University of Technology, 2007. Bachelor of Environmental Engineering, Kaunas University of Technology, 2005. Publications: author of 2 scientific publications. Research interests: protection of the atmosphere. 